\title{
A Review of the Characteristics of Early Apparatus and Methods for Hemoglobin Estimation
}

\author{
Young-Il Kwon \\ Department of Biomedical Laboratory Science, Shinhan University, Uijeongbu 11644, Korea
}

\section{Hemoglobin 평가를 위한 초기 기구의 특성 및 측정법 고찰}

\author{
권영일 \\ 신한대학교 임상병리학과
}

\begin{abstract}
Since the late 19th century, scientific logic and techniques have been used extensively in the field of clinical pathology, including many laboratory tests utilizing various apparatuses and instruments. Among the techniques to measure hemoglobin, the visual color comparison method was most popular around this time; the specific gravity method and gasometric method were not widely adopted. Instruments that use the visual color comparison method include Gowers' hemoglobinometer, von Fleischl's hemoglobinometer, Dare's hemoglobinometer, Oliver's hemoglobinometer, Haden-Hausser hemoglobinometer, and Spencer $\mathrm{Hb}$ meter. Initially, the visual color comparison methods were used to diluate and hemolyze blood with distilled water and then to measure its color. Later, these methods were further developed to measure hemoglobin without dilution, and improved with the formation of acid or alkaline hematin ensuring the stability of color development. Hammerschlag's method as well as the Schmaltz and Peiper's methods were based on specific gravity measurement, but they were not widely used. The gasometric method used the Van Slyke gasometer, indirectly measuring the hemoglobin concentration. This method provides the most accurate results. This survey examined the characteristics and limitations of hemoglobinometers and methods used to measure hemoglobin from the late 19th century to the earlyand mid-20th century. Moreover, this study aims to improve the understanding and applicability of the current methods and emerging technologies used in measuring hemoglobin. It is also expected that this investigation is the starting point to promote awareness of the need to organize historical data for a variety of historical relics of the diagnostic laboratory tests.
\end{abstract}

Key words: Hemoglobin, Early hemoglobinometers, Visual colorimeter, Specific gravity, Gasometer

This is an Open Access article distributed under the terms of the Creative Commons Attribution Non-Commercial License (http://creativecommons.org/licenses/by-nc/4.0) which permits unrestricted non-commercial use, distribution, and reproduction in any medium, provided the original work is properly cited.

Copyright () 2016 The Korean Society for Clinical Laboratory Science. All rights reserved.
Corresponding author: Young-II Kwon

Department of Biomedical Laboratory Science, Shinhan University, 95 Hoam-ro, Uijeongbu

11644, Korea

Tel: 82-31-870-3711

Fax: 82-31-870-3719

E-mail: ivdtechnology@gmail.com

Received: November 3, 2016

Revised $1^{\text {st: }}$ November 18, 2016

Revised $2^{\text {nd }}$ : November 19, 2016

Revised 3 ${ }^{\text {rd: }}$ November 20, 2016

Revised $4^{\text {th }}$ : November 20, 2016

Accepted: November 20, 2016

\section{서 론}

혈색소(hemoglobin, $\mathrm{Hgb}$ ) 측정은 빈혈을 진단하는데 있어 필 수적인 검사이다. 빈혈은 인류역사가 시작된 이래 아주 흔하게 발 생하는 질환으로 빈혈에 대한 근거는 4000년 전으로 거슬러 올라 간다[1]. 빈혈이라는 단어는 피가 없다는 그리스어로부터 유래되
었으며, 빈혈은 혈액에서 적혈구의 감소 혹은 혈색소의 감소로 정 의된다. 이것은 산소를 운반하는 혈액의 능력이 저하되었음을 의미 한다. 따라서 이와 같은 상태를 정확하게 진단하는 것은 매우 중요 한 일이었지만 이를 과학적 논리와 기술을 이용하여 측정할 수 있 는 도구들은 19세기 후반에서야 개발되기 시작하였다[2,3].

본 종설에서는 1800 년대 후반에서 1900 년대 초 · 중반에 사용된 
혈색소 측정방법과 기기(hemoglobinometer 혹은 hemometer) 의 특성을 조사하고 이를 통하여 현재의 측정방법과 기술에 대한 이해를 향상시키고자 하였다. 또한 근대과학의 태동기인 19세기 후반과 20세기 초의 과학적 논리와 기술들을 당시의 진단검사 측 정법과 기구들로 이해하는 것은 매우 흥미롭고 의미 있는 일이라 하겠다. 따라서 본 조사에서는 초기에 사용되었던 혈색소 측정방법 과 기기특성을 조사하기 위하여 100 여년 전의 진단검사 고서인 Graham Brown [2,4], Ewing [3,11], Abrams [5], Simon [6-8], Emerson [9], Bury [10], Todd [12-14] 등을 중심으로 고찰을 시도 하였다.

\section{본 론}

\section{Hemoglobin 생화학적 특징과 유도체의 물리화학적 특징}

헤모글로빈은 빈혈을 평가하는데 사용되는데 통상 적혈구용적 률(hematocrit, Hct)과 함께 사용된다. 혈색소는 우리 몸에 산소를 운반하는 단백질로 생명유지의 근원이라고 할 수 있다. 혈색소 분 자량은 64,458 Dalton이고 약 6\%의 헴(heme)와 94\%의 글로빈 (globin)으로 이루어져 있고 4개의 폴리펩타이드 사슬로 구성된 $\alpha_{2} \beta_{2}$ 사슬구조를 갖고 있다. 적혈구 한 개당 약 2 억8천개의 혈색소 가 존재하므로 적혈구 한 개는 최대 11 억개의 산소를 운반할 수 있 다. 혈색소는 1 그램당 최대 $1.39 \mathrm{~mL}$ 의 산소를 운반할 수 있다[15]. 혈색소는 매일 6.25 gram이 합성되는데 풋정상적혈모구(proerythroblast)와 그물적혈구(reticulocyte) 사이의 성숙과정에서 합 성된다[16].

생체 내의 혈색소는 산화혈색소(oxyhemoglobin, $\mathrm{HbO}_{2}$ ), 탈산 소혈색소(deoxyhemoglobin, $\mathrm{Hb}$ ), 그리고 메트헤모글로빈(methemoglobin, MetHb)으로 구분되는데, 혈색소는 산소가 결합되어 있을 때와산소가 결합되어 있지 않을 때 서로 다른 4 차구조를 갖는 다. 즉 알로스테릭(allosteric) 효과를 나타내는 단백질이다[17]. $\mathrm{MetHb}$ 은 heme구조 내의 $\mathrm{Fe}^{2+}$ 가 $\mathrm{Fe}^{3+}$ 로 산화된 형태를 말하고 정 상적으로 1-2\% 존재한다. 산화혈색소는 선홍색으로 $544 \mathrm{~nm}$ 와 $570 \mathrm{~nm}$ 파장에서 흡수극대를 보이며, 탈산소혈색소는 자홍색을 띄며 $555 \mathrm{~nm}$ 에서 흡수극대를 보인다. MetHb은 갈색을 보이며 $630 \mathrm{~nm}$ 에서 흡수극대를 보인다[18].

생체의 환경 및 조건 변화로 인해 생기는 혈색소 유도체로는 methemoglobin (MetHb), sulfhemoglobin (SulfHb), carboxyhemoglobin (COHb)이 있다. MetHb은 유전적 요인, 다양한 약물, 환경적 요인 그리고 세포방어기전의 감소로 발생한다. MetHb은 $\mathrm{Fe}^{3+}$ 을 가짐으로 인해 산소결합 능력이 감소하는데 이로 인해 $\mathrm{MetHb}$ 이 증가하면 조직에서 저산소증이 발생할 수 있다. SulfHb
은 hemoglobin의 헴에 황(sulphur)이 결합할 때 형성되는데 녹색 으로 보이며 산소를 운반할 수 없다. Sulphonamides가 붙은 약물 이나 화학물질의 작용에 의해 형성되거나 공기 중에 황이 있을 때 형성된다. 일단 형성되며 비가역적 상태가 되며, $\mathrm{RBC}$ 내에 남아있 게 된다. SulfHb은 cyanmethemoglobin법으로 측정할 수 없다. $\mathrm{COHb}$ 은 정상 혈색소가 일산화탄소에 노출되었을 때 형성된다. 혈 액에 $\mathrm{COHb}$ 이 높은 농도로 존재할 때는 다홍색을 보이며 혈색소와 는 가역적으로 결합한다[19].

\section{19 세기 후반에서 현재까지의 혈색소 측정법 변화와 동향}

혈색소 검사는 과거 19세기 후반부터 현재까지 다양하게 측정 기술을 향상시켜왔다. 19세기 후반에서 20세기 초반에는 혈색소 의 색이나 혈색소 유도체를 형성시켜 육안으로 표준색과 비교하는 방법이 사용되었다[3]. 이후 물리적 방법으로 황산구리(copper sulfate) 용액에 전혈을 적하하여 혈색소의 비중을 측정하는 방법 이 소개되었다[20]. 진단검사실에서 많이 사용되지는 않았지만 혈 색소에서 철을 분리하고 철함량을 정량하여 혈색소 양을 추정하는 화학적 방법(Jolles' Ferrometer)도 소개[6]되었는데 이 측정법은 시안메트헤모글로빈(cyanmethemoglobin, HiCN)법의 reference standard로 사용되었다. 이후 혈색소의 산소결합능력에 근거한 가 스정량법(gasometric method)으로 van Slyke 기구를 이용한 측 정법이 소개[21]되었다. 1940년대 이후 소개된 비색법(colorimetric method)은 alkaline hematin을 형성시켜 Beer의 법칙을 적용하여 혈색소 농도를 정량하는 방법으로 Duboscq colorimeter가 이용되었다[22,23]. 이후 분광광도계 개발로 더욱 정확한 혈색소 정량이 가능하게 되었다. 1960년대부터 혈액학분석기의 자동화가 시작되면서 대부분의 분석기에서 시안메트헤모글로빈 법을 활용하여 혈색소를 측정하였으며, 1966년에는 ICSH (International Council for Standardization in Hematology)에서 권고 한 시안메트헤모글로빈법이 국제표준법으로 제정되었다[24]. 이 방법은 현재도 대부분의 자동분석기에서 가장 일반적으로 활용되 고 있다. 2000년대에는 현장검사(point of care testing, POCT)의 수요가 증가하면서 습식화학(wet chemistry) 측정법 보다 더 간편 하고 신속하게 결과를 산출할 수 있는 센서기술이 도입되었다. 현 재 현장검사기기에 사용되는 측정법으로는 전기전도도를 이용하 여 적혈구용적률을 측정한 후 이 값에 0.34 를 곱하여 혈색소 값을 추정하는 방법과 modified azidemethemoglobin 반응을 이용한 방법, 측광방법(photometric method), 전기화학적 방법(electrochemistry method), 반사측광법(optical reflectance method) 등이 있다. 최근에는 산소포화도를 측정하는 pulse oximetry 기술 을 응용한 비침습적 pulse CO-oximetry가 혈색소 측정에 응용되 
고 있다. 이것은 $\mathrm{LED}$ 광을 이용하여 손가락에 가시광선과 적외선 영역의 빛을 통과시켜 산화헤모글로빈과 환원헤모글로빈 흡수비 율을 비교 측정하는 방법이다. 이는 지속적으로 환자의 혈색소 농 도를 측정할 수 있는 장점이 있어 기존의 침습적 혈색소 측정법의 대체 방법이 될 가능성이 높아 보인다[25-27]. 이와 같은 생체분광 학 기술은 혈색소 측정 외에 다양한 진단검사 분야에서 활용될 것 으로 전망된다. 이외에도 스마트폰 동글(dongle)을 이용한 혈색소 측정법들이 소개[28]되고 있어 추후 진단검사의 새로운 패러다임 도입과 적용에 분석전문가들의 적극적인 참여가 필요하다 하겠다.

\section{3. 초기 혈색소 측정방법과 기구 특성}

19세기 후반에서부터 20세기 초 - 중반까지 사용된 초기의 혈 색소 측정법과 기기의 대부분은 육안색조비교법(visual color comparison method)을 응용하였다. 이외에도 혈액의 비중을 측 정하여 간접적으로 혈색소 농도를 측정한 비중측정법(specific gravity method)도 이용되었으며, 가스정량법(gasometric method) 은 20세기 초 가장 정확한 방법으로 평가되어 측정과정의 표준화 에 중요한 역할을 하였지만 검사의 복잡성으로 인해 검사실에서는 거의 사용되지 않았다.

1) 육안색조비교법(visual color comparison method)

(1) Gower's hemoglobinometer

Gower가 개발한 혈색소 측정기구로 직경이 동일한 두개의 유 리튜브를 이용하는 방법이다(Fig. 1), 한쪽은 picrocarmine과 glycerin을 이용하여 만든 대조튜브로 정상혈액을 증류수로 희석

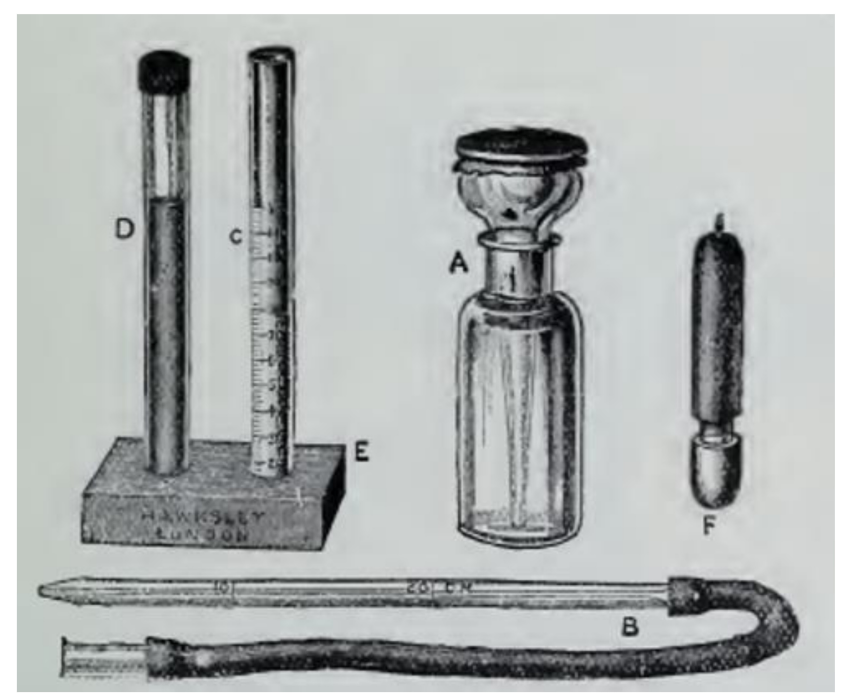

Fig. 1. Gowers' apparatus. A, pipette bottle for distilled water; B, capillary pipette; C, graduated tube; D, tube with standard dilution; $\mathrm{F}$, lancet for pricking the finger.
하여 $1 \%$ 가 되게 만든 색조와 일치시킨 튜브(D)이다. 즉 이 대조튜 브는 정상혈액 20 cubic milimeter (입방 밀리미터)를 증류수 1,980 cubic milimeter로 희석시켜 용혈시킨 색조와 동일한 색조 를 갖는다. 다른 튜브는 검체 튜브로 밑에서부터 위로 120 까지 눈 금이 그어져 있다(C). 검사시에는 이 튜브에 몇 방울의 증류수를 미 리 넣은 후, 환자의 손가락 측면을 lancet (F)을 이용하여 천자하고, 전용 pipette (B)를 이용하여 20 cubic milimeter까지 혈액을 흡입 한 후 pipette 외부의 혈액을 닦아내고 정확히 20 cubic milimeter 를 분주하였다. 그리고 정확한 분주를 위하여 pipette 내부를 증류 수로 씻어 혈액이 모두 검체로 이용되도록 하였다. 이어 dropper (A)를 이용하여 증류수를 한 방울씩 떨어뜨리면서 잘 혼화하고, 대 조튜브와 동일한 색조가 될 때까지 반복하여 증류수를 추가하였다. 대조튜브와 동일한 색조가 나타나면 검체튜브에 채워진 용액의 메 니스커스 눈금을 읽어 퍼센트를 기록하였는데 이 결과는 정상인 대 비 몇 \%의 혈색소량을 갖고 있는지를 평가한 것이다[5,7]. 이 결과 는 8-24\% 오류를 나타내는 것으로 평가되었다[8].

(2) von Fleischl's method

이 기구는 현미경구조를 연상시키는 형태를 갖고 있다(Fig. 2). 상단(stage) 바로 밑에는 쐐기 형태의 붉은색 컬러 유리막대가 장착 되어 있는데 이 유리막대 한 쪽 끝은 옅은 분홍색 시작해서 점차적 으로 반대 쪽으로 진한 붉은 색을 띠도록 염색되었다. 상단 아래 이 유리 막대를 끼우고 있는 프레임에는 색조에 따라 혈색소 비율과 대응하는 눈금이 0 에서 120 까지 표시되었다. 이 때 눈금 100 은 완 전하게 정상이라고 판단되는 사람의 검체를 이용하여 만든 기준 색 조다. 0 이 표기된 유리막대 부분이 가장 얇고, 120 으로 표기된 부분 이 가장 두껍게 쐐기 형태로 제작되었다. 이 프레임은 손으로 조정 나사를 돌려 이동시킬 수 있도록 제작되었다. 상단에는 $1.5 \mathrm{~cm}$ 높 이의 원통형 금속용기(cylindrical vessel)가 고정되어 있는데 바닥 은 투명한 유리로 제작되었고 원통의 중앙에는 금속판을 이용하여 양쪽을 동일한 크기로 수직으로 나누었다. 한 쪽은 혈액검체와 물 을 넣어 혈색소 농도를 판정하는 부분이고(white chamber) 다른 쪽은 컬러 유리막대의 색조를 혈액검체의 색조와 비교하도록 증류 수 만을 채우는 부분(red chamber)이다. 환자의 혈액을 모세관튜 브(6.5 cubic millimeters)에 채운 후 white chamber에 분주하고 증류수를 원통의 상단 끝까지 채워 희석하여 용혈시켰다. 이어서 red chamber에도 증류수를 상단 끝까지 채운 후 프레임을 좌우로 이동시켜 red chamber와 white chamber가 동일한 색조를 나타 내는 위치에 오면 프레임의 눈금을 읽어 혈색소 비율을 판정하였 다. 이 때 아래의 반사경으로 들어오는 빛은 태양광을 피하고 촛불 이나가스 불꽃을 사용하였다[7,8,10]. 이 방법 역시 Gower의 방법 과 마찬가지로 증류수로 희석된 혈액을 이용하여 혈색소를 측정하 

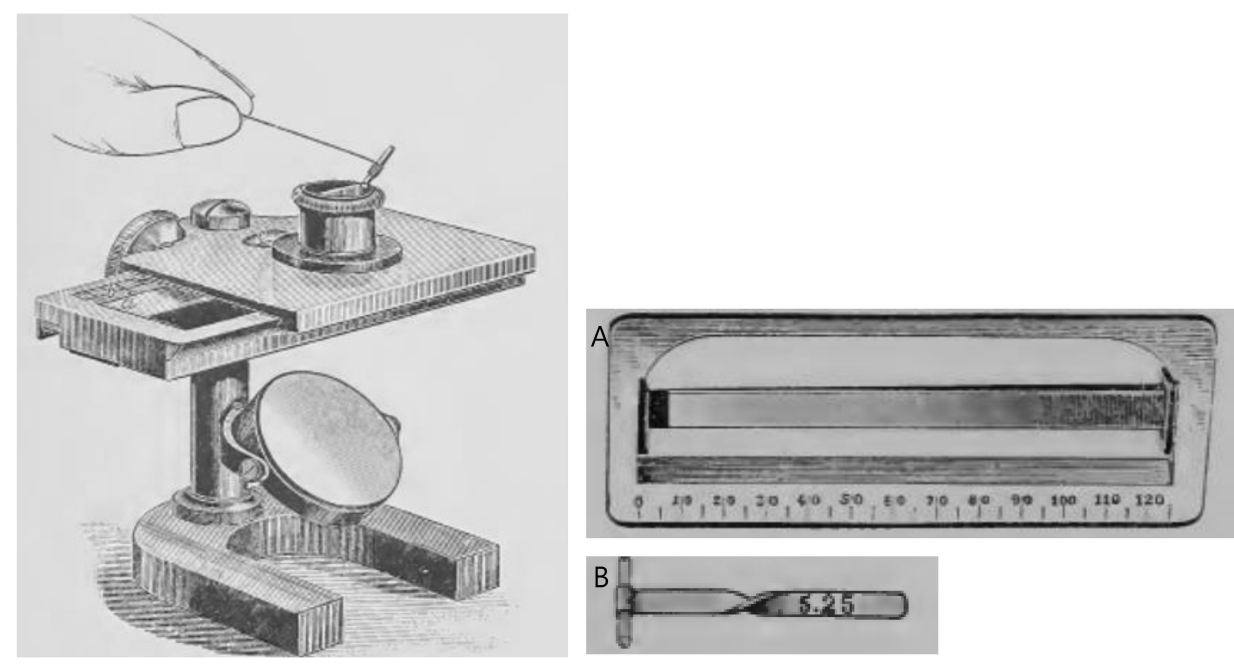

Fig. 2. von Fleischl's hemoglobinometer. A, narrow wedge-shaped piece of colored fitted in to a flame; $\mathrm{B}$, capillary tube to collect the blood.

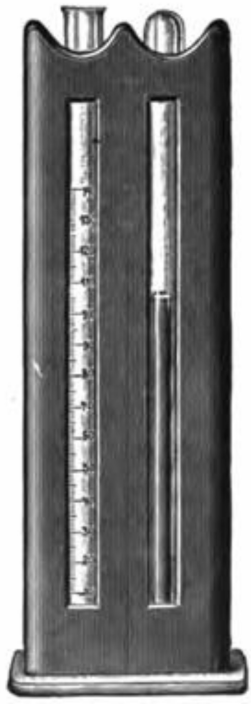

Fig. 3. Sahli's hemoglobinometer.

는 것이 단점이었지만 정확도를 약 $5 \%$ 이내로 줄여 혈색소 측정의 정확도를 개선한 것으로 평가되었다[12].

(3) Sahli hemoglobinometer

Sahli hemoglobinometer는 Gower 방법을 개선한 방법으로 1902년에 소개되었다(Fig. 3). Gower는 혈액검체 희석 시 물을 이 용하였지만 Sahli는 $1 / 10 \mathrm{~N} \mathrm{HCl}$ 을 사용하여 acid hematin을 형성 시켜 발색의 안정성을 향상시켰다. 이로 인해 Gower의 방법보다 더 나은 약 $5 \%$ 이내에서 정확도를 유지할 수 있게 되었다[12]. Sahli 방법은 간편성과 정확성으로 인해 초기 혈색소 측정도구 중 70년 대까지 가장 오랫동안 활용되었다.

(4) The Fleischl-Miescher method

이 기기는 Fleischl 기구보다 더 향상된 혈색소 측정을 위해 제작 되었는데 임상의사가 직접 사용하기 보다는 검사실용으로 더 적합
하도록 제작되었다. von Fleischl 기기와의 주요 차이점은 혈액량 을 더 정확하게 채취하고 희석하도록 hemacytometer에서 사용하 는 피펫을 사용하였고, 혈액검체 희석 시 물 대신 $0.1 \%$ sodium carbonate를 사용하여 발색 안전성을 향상시킨 것이다. 또한 컬러 유리막대는 더욱 정확한 색조를 갖도록 제작되었고, 상단의 원통 chamber를 덮을 수 있는 유리판과 금속 덮개도 추가하였다. 금속 덮개에는 가늘고 긴 홈을 만들고 이곳을 통하여 색조를 비교 관찰 하도록 함으로써 외부 빛에 의한 간섭을 최소화하였다[4,9,14].

(5) Oliver's hemoglobinometer

Oliver's hemoglobinometer는 임상검사에서 좋은 평가를 받 았다. Oliver's hemoglobinometer 구성은 손가락을 천자할 lancet (b)과 5 cubic millimeter의 혈액을 채우는 유리 모세관튜 브(c), 모세관 내의 혈액을 완전히 씻어낼 목적과 mixing chamber 에 증류수를 채울 목적으로 사용하는 dropper (d), 그리고 모세관 튜브에 채운 혈액을 분주하고 이를 물로 희석하고 용해시켜 혈색소 비율을 측정하는데 사용할 mixing chamber (e)로 구성되어 있다. Mixing chamber의 가장자리까지 정확하게 증류수를 채우면 혈액 이 모두 용해되는데 이 때 환자검체는 $1 \%$ 의 혈액농도가 되었다. 이 어서 chamber에 glass slip을 덮고 chamber의 색조와 표준색조디 스크(a)와 비교하여 혈색소 비율을 판독하였다(Fig. 4). 표준색조디 스크는 10 에서 120 까지 혈색소 농도에 따라 12 가지 색조를 갖는 디스크로 구성되었는데 2개의 세트로 제작되었다. 색조비교 시에 는 광원으로 촛불을 이용하였고 카메라 튜브를 이용하여 검체와 표 준색조디스크의 판독 정확성을 향상시켰다. 만일 혈액용액의 색조 가 아래 위 두 디스크의 중간 색조를 나타내는 경우에는 rider를 이 용하여 $1 \%$ 단위까지 측정하였다. Rider는 표준색조디스크 사이의 색조비율을 세분하여 측정하기 위해 제작된 사각형 컬러유리로 9 개가 한 세트로 제작되었지만[29,30], 통상 2.5와 5퍼센트를 측정 


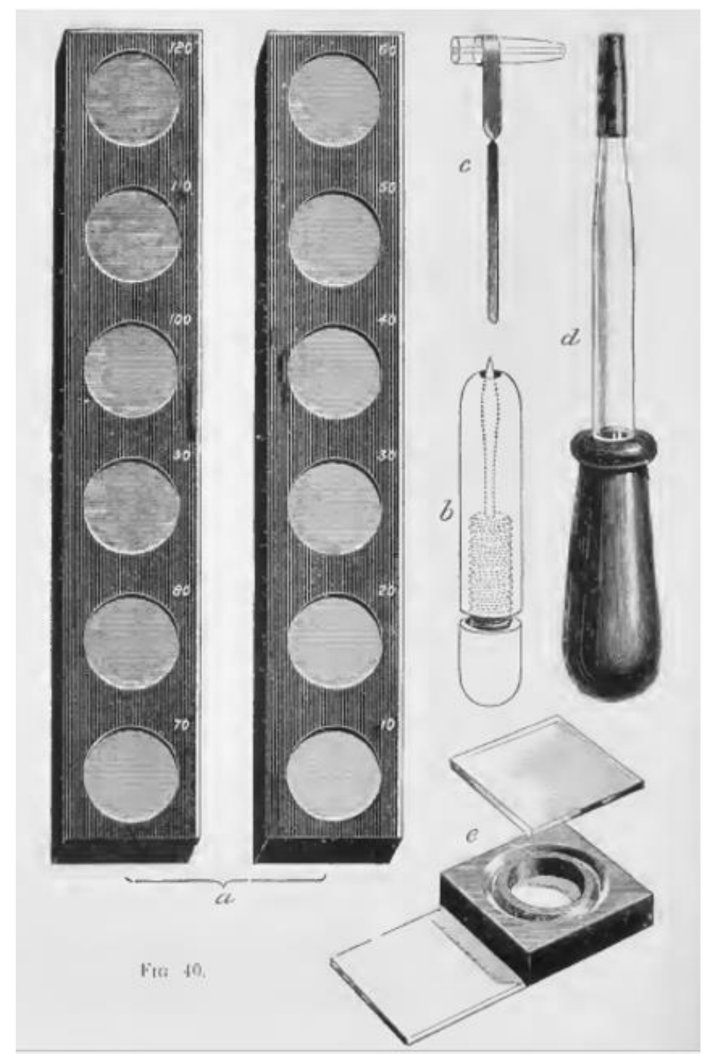

Fig. 4. Oliver's hemoglobinometer. a, standard discs; b, lancet; c, capillary tube to collect the blood; d, pipette; e, cell for comparison with the standard discs after diluting the blood.

할 수 있는 rider를 제작하여 이용하였다[6]. Rider는 표준색조디스 크 위에 중첩하여 올려 놓고 검체와 동일한 색조를 찾아 혈색소 비 율을 결정하였다. 이 방법은 Fleischl hemoglobinometer보다 편 리성은 떨어지지만 더 좋은 결과를 산출한 것으로 평가되었다. 그 러나당시 혈색소 검사를 위해 일반적으로 사용하기에는 기기 구매 비용이 비싼 단점을 갖고 있었다[4].

(6) Dare's hemoglobinometer

Dare hemoglobinometer (Fig. 5)의 필수구성은 혈액채취를 위 한 모세관 유리챔버(Fig. 5B)와 혈색소 비율을 측정하기 위해 대응 하는 색조를 원형으로 제작한 표준 유리컬러스케일(Fig. 5A), 그리 고 이를 관찰하기 위한 카메라 원통튜브이다. 즉 카메라 원통을 통 하여 검체를 넣은 유리챔버와 컬러스케일의 색조를 동시에 비교할 수 있는 동일한 크기의 두개의 구멍을 만들었다(Fig. 5C). 이때 양쪽 의 색조를 비교하기 위해 반대편에 광원을 설치하였는데 초기에는 촛불을 이용하였고 후에는 전구로 대체되어 판독의 용이성을 개선 하였다. 컬러스케일은 혈색소 비율을 10 에서 120 까지 판정할 수 있 도록 제작되었는데, 눈금 100에 해당하는 컬러는 혈액 $100 \mathrm{cc}$ 에 혈 색소 13.77 gram이 들어 있을 때의 혈색소 비율이다[14]. 각 컬러 스케일의 다양한 음영색은 황금 보라색을 착색시킨 프리즘을 이용

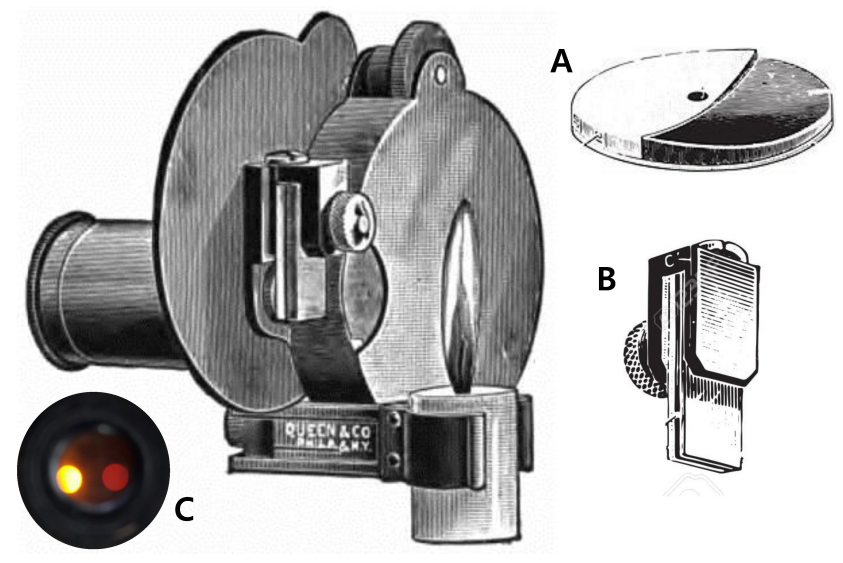

Fig. 5. Dare's hemoglobinometer. A, graduated standard color scale; B, automatic pipette; C, two apertures (standard color scale and sample) looking through the camera tube.

하여 반원 형태의 유리로 제작하였으며 고정축에 부착시켜 회전시 킴으로써 검체 색조와 비교하도록 하였다. 검체채집용 모세관 유리 챔버는 두 개의 작은 유리판을 겹쳐 놓은 챔버 형태로 모세관 현상 에 의해 유리판 안으로 혈액이 유입되도록 하였다. 혈액검체를 얻 기 위하여 손가락이나 귓불을 천자 후 혈액을 희석하지 않고 챔버 에 흡입시켜 측정하는 방식이므로 혈액이 응고되기 전에 신속하게 판독하는 것이 중요하였다. 혈액 희석과정이 없어 검사의 편리성이 향상되었고 또한 희석으로 인한 오류를 줄이는 효과가 있었다. 이 기구는 1900년대 초 가장 정확한 혈색소 측정기구 중 하나로 평가 되었다[12]. 그러나 백혈병환자의 혈액용액은 혼탁으로 인해 명백 하게 오류를 나타낸다고 기록되어 있다. 측정결과는 Fleischl 기구 로 측정한 것 보다 약간 더 높게 측정되었지만, Oliver hemoglobinometer로 측정한 결과와는 유사한 결과를 보여 주었다[30].

(7) Haldane's hemoglobinometer

Haldane혈색소 측정법은 Gower 측정방법을 개선시킨 것이다. 건강한 성인남자들의 평균 혈액을 이용하여 $1 \%$ 의 표준용액을 만 들어 사용하였다. Haldane의 혈색소 측정방법은 석탄가스를 이용 하여 혈액검체에 일산화탄소(CO)를 포화시켜 cyanmethemoglobin을 형성시킨 후 증류수로 적혈구를 용혈시키면서 나타나는 분홍 색조를 표준튜브와 동일한 색조가 되도록 하여 혈색소의 비율 을 판정하는 방법이다. Cyanmethemoglobin을 이용하여 측정하 는 방법 중 가장 오래된 방법이다. 그러나 표준튜브의 색이 빠르게 사라지는 등 상업적으로 표준튜브를 신뢰할 수 없는 단점을 갖고 있었다. 또한 $\mathrm{CO}$ 공급이 필요한 실험 복잡성이 문제가 되어 널리 사용되지는 않았다[4,11,23].

(8) Haden-Hausser hemoglobinometer

백혈구 피펫을 이용하여 혈액을 $0.1 \mathrm{~N} \mathrm{HCl}$ 로 20 배 희석하여 hemoglobin이 acid hematin으로 전환되도록 30분을 기다린 후 
이 때 생긴 색조를 비교슬라이드의 기준색조와 비교하는 측정법이 다. 이 기기는 색조 비교 시 조명램프나 일광필터를 사용하여 색조 비교가 가능하도록 제작되었다. 이 기기의 주요구성은 혈색소량에 따라 색조의 차이가 있는 비교슬라이드(B)와 이를 장착할 수 있는 이동형 캐리어(A) 그리고 이것을 덮는 커버글라스(C), 눈금을 읽을 수 있는 확대경(D)이 달려있는 구조이다(Fig. 6). 비교슬라이드의 홈이 파진 곳(E)에 희석한 검체를 흘러 들어가게 한 후 비교슬라이 드의 기준색조(아래)와 비교하는데 혈액검체(위)와 동일 색조가 나 타나는 위치의 농도를 읽는다(Fig. 6B, 6G). 비교슬라이드에는 혈 색소 농도가 7.5에서 $19 \mathrm{gram}$ 까지 표기되어 있다. 이 기준스케일 의 색조는 van Slyke의 manometeric blood gas 측정법으로 얻은 산소결합능력을 이용하여 설정하였다. 혈색소량으로의 변환은 헤 모글로빈 1 gram 당 산소 $1.34 \mathrm{~mL}$ 산소결합능력을 가진다는 Hüfner 변환계수에 근거하여 계산된 것이다[31-34].

(9) Spencer $\mathrm{Hb}$ meter

미국 American Optical사에서 출시한 혈색소 측정기로 1950 년부터 1975년까지 사용되었다(Fig. 7). Chamber glass에 혈액을 올려 놓은 후 saponin을 이용하여 혈액을 용혈시켜 oxyhemoglobin을 형성시키고(Fig. 7A), chamber를 측정기 옆면의 홈(slot) 에 넣고 내부에 장착되어 있는 기준 유리색조계와 비교하는 기기이
다. 광원으로 램프가 내장되어 있으며 초록색 필터를 채택하였다. 스케일 이동스위치를 앞뒤로 이동시키면서 접안렌즈를 통하여 관 찰된 분할화면에 기준색조와 검체가 동일한 색조가 나오면 측면상 단 눈금에서 혈색소 농도를 읽는다(Fig. $7 \mathrm{~B})$. 측면하단 눈금은 집단 별 정상치 $(15.7,14.5,13.8 \mathrm{gram} / 100 \mathrm{~mL})$ 대비 환자의 혈색소 비 율을 읽을 수 있도록 눈금표기를 하였다.

(10) Tallquist scale method/ WHO hemoglobin colour scale method

Tallquist 스케일 방법은 가장 대중적으로 사용되었던 혈색소 측 정법으로 주머니에 넣을 수 있는 작은 책형태로 제작되었다. 책 내 에는 혈액흡수지 시트와 혈색소 비교를 위해 인쇄된 표준색조의 컬 러스케일로 구성되어 있다(Fig. 8A). 시트는 흰색으로 적정한 두께 를 갖는 여지를 사용하였으며, 컬러스케일은 색조에 따라 10 에서 100 까지의 범위를 가지며 10 단위로 스케일화 하였다. 지름이 약 5-6 mm 되도록 혈액 한 방울을 흡수여지에 묻히고 혈액습기로 인 한 광택이 사라질 때 표준 컬러스케일과 비교하는 방법이다. 공기 가 혈색소를 검게 하기 전에 컬러스케일의 색조와 비교하는 것도 주요 주의사항이다. 통상적으로 일광을 이용하여 비교하였다. 이 방법의 정확도는 $10-20 \%$ 의 오류를 갖고 있어 결과 사용이 제한적 이었지만 당시의 치료결과를 관리하는 방법으로는 충분하다는 의
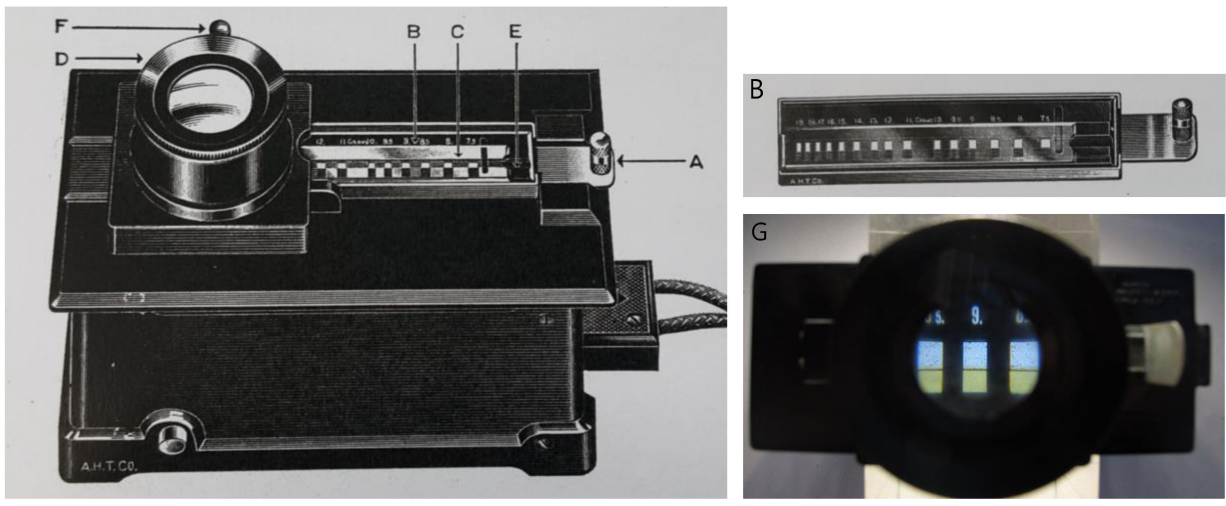

Fig. 6. Haden-Hausser hemoglobinometer. A, metal holder; B, comparator slide; C, Rectangular cover glass; D, reading microscope; $\mathrm{E}$, wedge-shaped channel; F, shutter; G, comparator slide looking through the reading microscope.
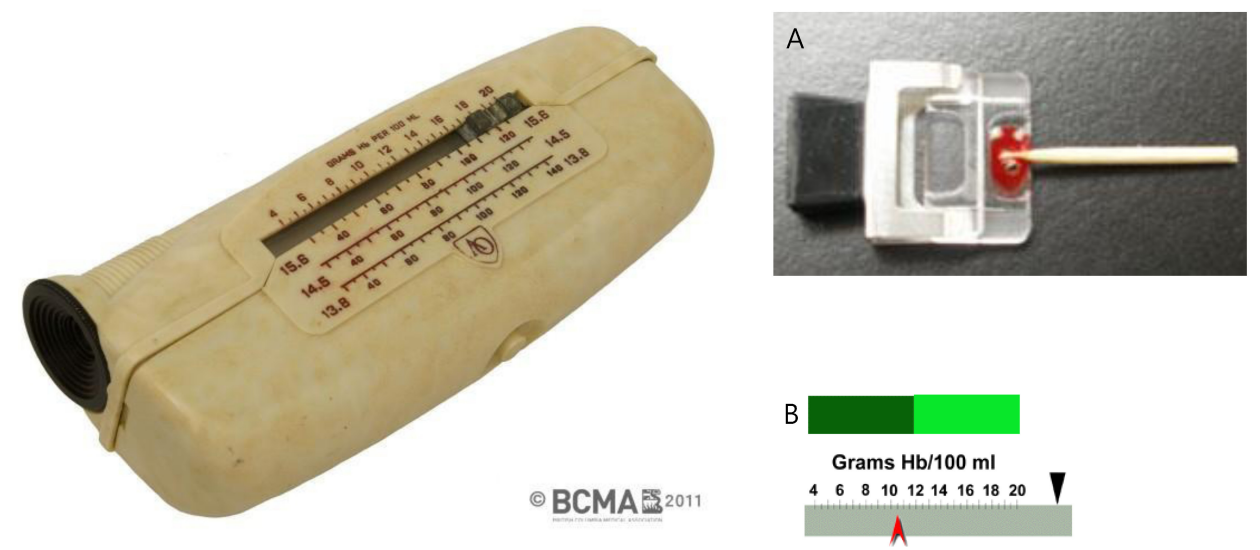

Fig. 7. Spencer Hb meter. A, sample chamber and saponin coated applicator; B, hemolyzed blood sample with a standard color image looking through the eyepiece and hemoglobin concentration scale. 
견도 제시되었다. 그러나 Tallquist가 hemometer로 비교한 실험 에서는 오차한계가 $10 \%$ 를 넘지 않는다고 주장하기도 하였다 $[8,13,30]$.

Tallquist 스케일을 이용한 방법과 유사한 혈색소 평가방법이 WHO hemoglobin colour scale이다. 이 방법은 WHO/NGO 등 에서 빈혈퇴치를 위해 빈곤국을 대상으로 추천되고 있다. WHO hemoglobin colour scale은 혈색소 측정결과를 비율을 표시한 Tallquist 방법과는 다르게 4 에서 $14 \mathrm{~g} / \mathrm{dL}$ 까지 판독이 가능하도록 단위를 이용하여 스케일 범위를 설정하였으며 판독간격은 $2 \mathrm{~g} / \mathrm{dL}$ 이다(Fig. 8B). WHO hemoglobin colour scale을 이용한 빈혈진 단 연구에 의하면 민감도와 특이도가 다양하게 평가되어 있다. 그 러나 빈혈진단의 신속성, 간편성 및 비용 등에서 잠재력과 합리성 을 갖추고 있다는 주장[35]과 빈혈과 혈액기증자를 대상으로 선별 하는데 있어 정확도와 정밀도가 임상적으로 허용 가능하며, 항응고 정맥혈액과 모세혈액 간에 차이가 없다는 연구결과가 보고되어 있 다[36]. 그러나 유용성과 안전성을 위해 검사지침을 엄격하게 지킬 것을 권고하는 연구 등도 보고되어 있다[37].
2) 비중측정법(specific gravity method)

(1) Hammerschlag method

혈색소 비율에 따라 혈액의 비중이 다양하게 변화한다는 것에 근거하여 혈액비중을 측정하고 이를 이용하여 혈색소의 비율을 결 정하는 간접적인 측정방법이다. 이 방법은 많은 백혈구수가 나타나 는 백혈병을 제외하면 상당히 정확한 결과를 산출한다고 평가되어 있다. Urinometer튜브에 클로로포름과 벤젠을 섞어 이 혼합물의 비중이 혈액의 비중과 유사하도록 조정한 후 작은 구경의 피펫을 이용하여 혈액 한 방울을 추가한다. 혈액방울이 표면 근처에 뜨면 벤젠을 약간 추가한다. 만일 바닥에 가라앉을 경우에는 클로로포름 을 약간 추가하여 비중을 더 높인다. 만일 혈액방울이 중간 근처에 정지상태로 있게 되면 이 때 혼합물은 혈액과 같은 비중을 갖는다. Urinometer의 비중을 읽고 이에 해당하는 헤모글로빈 비율을 얻 는다(Table 1). 이 때 혈색소의 퍼센트는 Fleischl hemoglobinometer를 이용하여 측정한 값을 사용하였다[12]. Hammerschlag 에 의하면 정상 남자혈액의 비중은 1.057 에서 1.066 까지이고, 여 자의 경우 1.054 에서 1.061 까지이다[29]. 이후에 비중을 이용한 측정법은 황산구리 $\left(\mathrm{CuSO}_{4}\right)$ 를 이용하는 방법[38]으로 바뀌어 활용
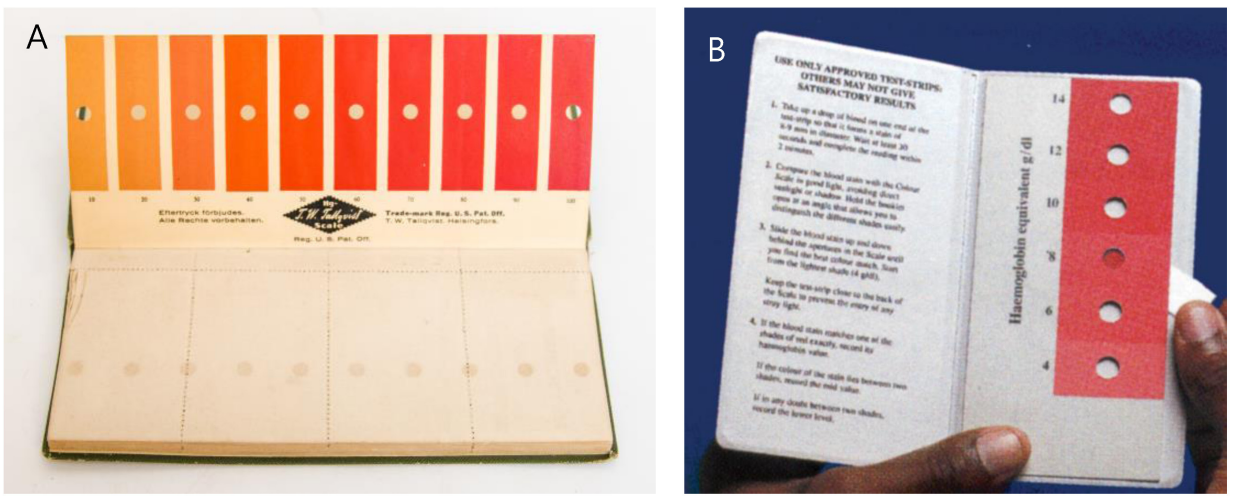

Fig. 8. (A) Tallquist colour scale; (B) WHO hemoglobin colour scale scale.

Table 1. The hemoglobin percent of Hammerschlag and Schmaltz and Peiper according to the specific gravity measurement [19]

\begin{tabular}{cccc}
\hline $\begin{array}{c}\text { Specific gravity according to } \\
\text { Hammerschlag }\end{array}$ & $\begin{array}{c}\text { Hemoglobin } \\
(\%)\end{array}$ & $\begin{array}{c}\text { Specific gravity according to } \\
\text { Schmaltz and Peiper }\end{array}$ & $\begin{array}{c}\text { Hemoglobin } \\
(\%)\end{array}$ \\
\hline $1.033-1.035$ & $25-30$ & 1.030 & 20 \\
$1.035-1.038$ & $30-35$ & 1.035 & 30 \\
$1.038-1.040$ & $35-40$ & 1.038 & 35 \\
$1.040-1.045$ & $40-45$ & 1.041 & 40 \\
$1.045-1.048$ & $45-55$ & 1.0425 & 45 \\
$1.048-1.050$ & $55-65$ & 1.0455 & 50 \\
$1.050-1.053$ & $65-70$ & 1.048 & 55 \\
$1.053-1.055$ & $70-75$ & 1.049 & 60 \\
$1.055-1.057$ & $75-85$ & 1.051 & 65 \\
$1.057-1.060$ & $85-95$ & 1.052 & 70 \\
& & 1.0535 & 75 \\
\end{tabular}


도가 크게 확대되었다.

(2) Schmaltz and Peiper's method

Schmaltz와 Peiper 방법은 정교한 측정이 가능한 곳에서 실시 할 수 있는 방법으로 비중을 이용하여 혈색소 비율을 측정하는 Hammerschlag 방법이 보다 정교하게 개선된 방법이다[7]. 당시 Fleischl hemometer보다 빈혈평가에 있어 더 우선해야 한다는 주 장도 있었지만 측정의 복잡성으로 인해 일반적으로 활용되지는 못 했다. 길이가 $12 \mathrm{~cm}$, 폭이 $1.5 \mathrm{~mm}$, 끝지름이 $0.75 \mathrm{~mm}$ 로 가늘어지 는 모세관에 혈액을 채우고 주의 깊게 무게를 측정한 후 이 때 동량 의 증류수 무게로 혈액검체의 무게를 나누어 혈액의 비중을 계산하 는 방식이었다(Table 1).

\section{3) 가스정량법(gasometric method)}

가스정량법은 van Slyke 장치를 이용하여 기체의 부피를 추정 하고 이를 이용하여 혈색소 농도를 계산하는 20세기 초 가장 정확
한 방법이었다. 즉 혈색소 $1 \mathrm{gram}$ 에는 약 $1.34 \mathrm{~mL}$ 의 산소가 결합한 다는 것에 근거하여 산소결합능력을 측정하고 이것을 이용하여 간 접적으로 혈색소량을 측정하는 방식이었다. 그러나 측정과정이 복 잡하고 시간 소모가 많았기 때문에 진단검사실에서는 사용되지 않 았다. 혈색소 측정과정의 표준화를 위한 기준방법으로 사용되었으 며 주로 연구분야에서 선호되었던 방법이다[21].

\section{결 론}

1900 년대를 전후로 의사들이 혈색소측정법과 기기들을 선택하 는데 있어 가장 중요한 요소는 그들의 욕구를 충족시키는 것이었 다. 그러나 어느 방법이든 연습은 정확도를 향상시키기 위한 필수 적 요소였다. 처음으로 과학적 논리를 갖춘 초기 Gower hemoglobinometer는 Sahli에서 Haldane까지 개선되었다. 이 중 Sahli hemoglobinometer는 검사자들에게 가장 만족스런 평가를 받은

Table 2. Characteristics, advantages and disadvantages according to method of hemoglobin estimation

\begin{tabular}{|c|c|c|c|}
\hline & 특징 & 장점 & 단점 \\
\hline Gower's hemoglobinometer & $\begin{array}{l}\text { - 증류수로 희석 } \\
\text { - 표준색조의 대조튜브 사용 }\end{array}$ & - 간편 & -낮은 정확도(8-24\% 오류) \\
\hline von Fleischl's method & $\begin{array}{l}\text { - 증류수로 희석 } \\
\text { - 쐐기 형태의 붉은색 컬러유리 대조막대 } \\
\text { 이용 }\end{array}$ & $\begin{array}{l}\text { - Gower's hemoglobinometer보다 } \\
\text { 정확도 개선(5\% 오류) }\end{array}$ & \\
\hline Sahli hemoglobinometer & $\begin{array}{l}\text { - } \mathrm{HCl} \text { 로 희석 } \\
\text { - Acid hematin 형성 }\end{array}$ & $\begin{array}{l}\text { - 간편 } \\
\text { - Gower's hemoglobinometer 보다 } \\
\text { 정확도 향상 }\end{array}$ & \\
\hline Fleischl-Miescher method & $\begin{array}{l}\text { - } 0.1 \% \text { sodium carbonate를 } \\
\text { 사용하여 발색 안전성 향상 }\end{array}$ & $\begin{array}{l}\text { - von Fleischl's method보다 정확도 } \\
\text { 향상 } \\
\text { - 외부 빛에 의한 간섭 최소화 }\end{array}$ & $\begin{array}{l}\text {-복잡 } \\
\text {-전문가 분석 }\end{array}$ \\
\hline Oliver's hemoglobinometer & $\begin{array}{l}\text { - 증류수로 희석 } \\
\text { - 카메라 튜브로 판독 }\end{array}$ & $\begin{array}{l}\text { - 판독 정확성 향상 } \\
\text { - } 1 \% \text { 단위까지 측정 }\end{array}$ & $\begin{array}{l}\text {-편리성 저하 } \\
\text {-고가의 구매비용 }\end{array}$ \\
\hline Dare's hemoglobinometer & $\begin{array}{l}\text { - 원형 표준유리 컬러스케일 사용 } \\
\text { - 혈액을 희석하지 않고 유리챔버로 측정 } \\
\text { - 광원이용 } \\
\text { - 카메라원통으로 판독 }\end{array}$ & $\begin{array}{l}\text { - 편리성 및 간편성 향상 } \\
\text { - 희석으로 인한 오류 감소 } \\
\text { - 정확 }\end{array}$ & $\begin{array}{l}\text {-고가의 기기 } \\
\text {-혈액응고 시 오류 } \\
\text {-검체혼탁 시 오류 }\end{array}$ \\
\hline Haldane's hemoglobinometer & $\begin{array}{l}\text { - 표준튜브 사용 } \\
\text { - cyanmethemoglobin 형성 }\end{array}$ & - Gower 측정법을 개선 & $\begin{array}{l}\text {-표준튜브 색조의 불안정성 } \\
\text {-실험 복잡성 }\end{array}$ \\
\hline $\begin{array}{l}\text { Haden-Hausser } \\
\text { hemoglobinometer }\end{array}$ & $\begin{array}{l}\text { - } \mathrm{HCl} \text { 로 희석 } \\
\text { - Acid hematin 형성 } \\
\text { - 혈색소 농도를 측정 }\end{array}$ & $\begin{array}{l}\text { - 정확도 개선 } \\
\text { - 측정범위 확대 }\end{array}$ & -실험 난이성 \\
\hline Spencer $\mathrm{Hb}$ meter & $\begin{array}{l}\text { - Saponin으로 검체를 용혈 } \\
\text { - Oxyhemoglobin 형성 } \\
\text { - 광원으로 램프이용 } \\
\text { - 혈색소 농도를 측정 } \\
\text { - 혈색소 비율도 제공 }\end{array}$ & - 간편 & \\
\hline $\begin{array}{l}\text { Tallquist scale method/WHO } \\
\text { hemoglobin colour scale method }\end{array}$ & $\begin{array}{l}\text { - Filter paper에 blood spot } \\
\text { - 기준 색조표 }\end{array}$ & $\begin{array}{l}\text { - 매우 간편 } \\
\text { - 시약이나 측정기구 불필요 } \\
\text { - 저비용 } \\
\text { - 현장성 }\end{array}$ & $\begin{array}{l}\text {-온도, 습도, 빛에 의한 영향 } \\
\text {-낮은 정확도 } \\
\text {-검사자간 편차 }\end{array}$ \\
\hline Hammerschlag method & $\begin{array}{l}\text { - 혈액비중으로 혈색소 비율 결정 } \\
\text { - Urinometer 이용 }\end{array}$ & - 높은 정확도 & $\begin{array}{l}\text {-실험 난이성 } \\
\text {-백혈병환자 오류 }\end{array}$ \\
\hline Schmaltz and Peiper's method & - 증류수 무게와 혈액검체 무게 비교 & $\begin{array}{l}\text { - Hammerschlag 방법 보다 정확도 } \\
\text { 개선 }\end{array}$ & $\begin{array}{l}\text {-정교한 측정기구 필요 } \\
\text {-측정 복잡성 }\end{array}$ \\
\hline Gasometric method & $\begin{array}{l}\text { - 기체부피를 측정하여 } \mathrm{Hgb} \text { 농도계산 } \\
\text { - Hgb 측정 기준방법 }\end{array}$ & - 20세기 초 가장 정확한 방법 & -주로 연구분야에서 사용 \\
\hline
\end{tabular}


기기였다고 판단되며 간편성과 정확성으로 인해 70 년대까지 활용 되었다. 당시 표준기기로 인정되었던 von Fleischl 기기와 이를 변 형시켜 정확도를 향상시킨 von Fleischl-Miescher기기가 좋은 평 가를 받았지만 분석의 복잡성과 난이성이 문제점으로 지적되었다. Oliver hemoglobinometer는 색조계(tintometer)를 매우 훌륭하 게 활용한 장비로 평가되었으며 von Fleischl-Miescher기기보다 정확도나 사용 난이도 측면에서 좋은 평가를 받았다. Dare hemoglobinometer는 정확한 결과를 산출하는 가장 좋은 기기로 평가 받았다. 그러나이 분석방법 역시 고비용과 Sahli 기기 보다 더 나은 정확도를 보여주는 것에 대해 의심을 갖게 되었고 좀 더 편리 하고 정확도를 향상시킨 Haden 방법으로 대체되었다. 비중을 이 용한 측정방법은 특별한 기기없이 간단하게 혈색소를 측정할 수 있 는 매우 유용한 방법으로 평가되었지만 사용이 일반화되지는 않았 다. Tallquist scale은 많은 의사들에게 저비용과 편리성 측면에서 좋은 평가가 있었지만 다른 측정법에 비해 정확도 낮은 단점이 있 었다. 그러나 WHO colour scale은 아직도 저개발국가에서 빈혈 을 진단하고 관리하는데 있어 간단하고 비용효율적으로 사용할 수 있다는 측면에서 유용성을 높게 평가하고 있다. 본 종설에서 다루 어진 초기 혈색소 측정법에 대한 특징과 장 - 단점을 Table 2에 요 약하였다.

과거 진단검사 측정법과 기구들을 조사하고 학술적 체계를 구축 하는 것은 진단검사를 수행하는 전문가들에게 매우 필요한 작업이 라 사료된다. 본 조사에서는 100 여년 전의 고서와 문헌 그리고 실 제 유물을 통하여 혈색소 측정에 관한 귀중한 자료를 획득하고 정 리하였다. 이는 과거와 현재 그리고 미래를 조망할 수 있도록 진단 검사의 기술적 체계를 실질화하고 역사적 가치를 공유한다는데 매 우 큰 의미가 있다고 하겠다.

\section{요 약}

19세기 후반부터 과학적 논리와 기술이 임상병리학 분야에 적 극적으로 활용되기 시작하였다. 이로 인해 많은 검사들이 도구와 기기를 이용하기 시작하였다. 이 때 등장한 혈색소 측정법 중에서 육안색조비교법이 일반적으로 사용되었고, 비중측정법과 가스정 량법은 활용도가 낮았다. 육안색조비교법을 적용한 기기로는 Gowers' hemoglobinometer, von Fleischl's hemoglobinometer, Dare's hemoglobinometer, Oliver's hemoglobinometer 그리 고 Haden-Hausser hemoglobinometer, Spencer Hb meter 등 이 있다. 육안색조비색법은 초기에 혈액을 증류수를 이용하여 희석 하고 용혈시킨 후 색조를 측정하는 방법을 활용하였지만, 이후 측 정방법을 개선하면서 혈액을 희석없이 측정하거나 발색의 안전성
을 위해 acid 혹은 alkaline hematin을 형성시키는 방법들로 발전 하였다. 비중을 이용한 측정법으로 Hammerschlag method와 Schmaltz and Peiper's method가 활용되었지만 대중적으로 사용 되지는 않았다. 가스정량법은 van Slyke 장치를 이용하여 간접적 으로 헤모글로빈 농도를 추정하는 방법으로 가장 정확한 결과를 제 공하였다. 본 조사에서는 19 세기 후반과 20세기 초 - 중반까지 사 용된 혈색소 측정기기와 측정법에 대한 특징 및 제한점 등을 알아 보았고, 이를 통하여 현재의 측정방법 및 새롭게 등장하는 기술들 에 대한 이해와 응용력을 향상시키고자 하였다. 또한 이번 조사가 진단검사 기술분야의 다양한 역사유물에 대한 고찰뿐만 아니라 역 사자료 체계화에 대한 필요성을 자각하는 시발점이 되기를 희망한다.

Acknowledgements: 본 조사에 임상병리학 분야의 역사자료와 희귀자료를 제공하고 학술자문에 응해준 성현메디텍(대표 차경환) 진단검사역사전시관에 감사드린다.

Funding: None

Conflict of interest: None

\section{References}

1. Tayles N. Anemia, genetic diseases, and malaria in prehistoric mainland Southeast Asia. Am J Phys Anthropol. 1996;101(1):11 -27 .

2. Graham Brown J. Medical Diagnosis: A manual of clinical method. 1st ed. London: Simpkin, Marshall; 1882. p66-67.

3. Ewing J. Clinical pathology of the blood; A treatise on the general principles and special applications of hematology. 1st ed. Philadelphia and New York: Lea Brothers; 1901. p38-46.

4. Graham Brown JJ, Ritchie WT. Medical diagnosis: A manual of clinical method for practitioners and students. 5th ed. Edinburgh \& London: William Green \& Sons; 1906. p96-101.

5. Abrams A. Manual of clinical diagnosis. Revised 2nd ed. San Francisco: S. Carson; 1892. p 95-96.

6. Simon CE. A manual of clinical diagnosis by means of microscopic and chemical methods for students, hospital physicians, and practitioners. 5th ed. Philadelphia and New York: Lea \& Brothers; 1904. p158-162.

7. Simon CE. A manual of clinical diagnosis by means of microscopic and chemical methods for students, hospital physicians, and practitioners. 2nd ed. Philadelphia and New York: Lea \& Brothers; 1897. p32-36.

8. Simon CE. A manual of clinical diagnosis by means of microscopic and chemical methods for students, hospital physicians, and practitioners. 9th ed. Philadelphia and New York: Lea \& Brothers; 1918. p91-92.

9. Emerson CP. Clinical diagnosis a text-book of clinical microscopy and clinical chemistry for medical students, laboratory workers, and practitioners of medicine. 3nd ed. Philadelphia and London: Lippincott; 1911. p521-523. 
10. Bury J. Clinical medicine: A manual for the use of students and junior practitioners. 2nd ed. London: Charles Griffin; 1898. p267-269.

11. Ewing J. Clinical pathology of the blood; A treatise on the general principles and special applications of hematology. 2nd ed. Philadelphia and New York: Lea Brothers; 1904. p44.

12. Todd JC. A manual of clinical diagnosis. 1st ed. Philadelphia and London: W.B. Saunders; 1908. p142-149.

13. Todd JC. A manual of clinical diagnosis. 2nd ed. Philadelphia and London: W.B. Saunders; 1912. p192.

14. Todd JC. A manual of clinical diagnosis. 4th ed. Philadelphia and London: W.B. Saunders; 1919. p269-270.

15. Pittman RN, San Rafael. Regulation of tissue oxygenation. CA: Morgan \& Claypool Life Sciences; 2011. [cited 2016 September 12]. Available from: http://www.ncbi.nlm.nih.gov/books/NBK54103/.

16. Knowles DM. Neoplastic hematopathology. 2nd ed. Philadelphia: Lippincott Williams \& Wilkins; 2001. p11.

17. Campbell MK, Farrell SO. Biochemistry. 6th ed. Bermont: Thomson Brooks / Cole; 2009. p106-112.

18. Zijlstra WG, Buursma A, Meeuwsen-van der Roest WP. Absorption spectra of human fetal and adult oxyhemoglobin, de-oxyhemoglobin, carboxyhemoglobin, and methemoglobin. Clin Chem. 1991;37(9):1633-1638.

19. van Kampen EJ, Zijlstra WG. Determination of hemoglobin and its derivatives. Adv Clin Chem. 1966;8:141-187.

20. Phillips RA, Van Slyke DD, Hamilton PB, Dole VP, Emerson K Jr, Archibald RM. Copper sulphate methods for measuring specific gravities of whole blood and plasma. Bull US Army Med Dept. 1943;71:66-83.

21. Van Slyke DD, Neill JM. The determination of gases in blood and other solutions by vacuum extraction and manometric measurement. I J Biol Chem. 1924;61:523-543.

22. Clegg JW, King EJ. Estimation of haemoglobin by the alkaline haematin method. Br Med J. 1942;19:329-333.

23. Cummer CL. A manual of clinical laboratory methods. Philadelphia and New York: Lea \& Febiger; 1922. p19.

24. Byun DH. Fundamental evaluation of new method for hemoglobin determination by using sodium azide. Korean J Clin Lab Sci. 1993;25:176-180.

25. Timma U, Leena G, Lewisa E, McGrathb D, Kraitlc J, Ewaldc H. Non-invasive optical real-time measurement of total hemoglo- bin content. Procedia Engineering 5. 2010;488-491.

26. Hueber DM, Franceschini MA, Ma HY, Zhang Q, Ballesteros JR, Fantini S, et al. Non-invasive and quantitative near-infrared haemoglobin spectrometry in the piglet brain during hypoxic stress, using a frequency-domain multidistance instrument. Phys Med Biol. 2001;46:41-62.

27. Barker SJ, Shander A, Ramsay MA. Continuous noninvasive hemoglobin monitoring: A measured response to a critical review. Anesth Analg. 2016;122(2): 565-572.

28. Guo T, Patnaik R, Kuhlmann K, Rai AJ, Sia SK. Smartphone dongle for simultaneous measurement of hemoglobin concentration and detection of HIV antibodies. Lab Chip. 2015;15(17):3514-3520.

29. Palisade Manufacturing Company. The essential of hematology: A practical guide to the clinical examination of the blood for diagnostic purpose. New York: Palisade Manufacturing Company; 1900. p39-41.

30. Dacosta JC. Clinical hematology: A practical to the examination of the blood with reference to diagnosis. 1st ed. Philadelphia: Blakiston's Son; 1902. p25-39.

31. Newcomer HS. Absorption spectra of acid hematin, oxyhemoglobin and carbon monoxide hemoglobin. J Biol Chem. 1919;37(3):465-469.

32. Haden RL. A method for the determination of hemoglobin. J Lab Clin Med. 1923;8(6):411-414.

33. Haden RL. A new hemoglobinometer. J Lab Clin Med. 1930; 16(1):68-73.

34. Razek J. Test of Haden-Hausser hemoglobinometer. J Lab Clin Med. 1931;16(6):583-591.

35. Critchley J, Bates I. Haemoglobin colour scale for anaemia diagnosis where there is no laboratory: a systematic review. Int J Epidemiol. 2005;34:1425-1434.

36. Timan IS, Tatsumi N, Aulia D, Wangsasaputra E. Comparison of haemoglobinometry by WHO haemoglobin colour scale and copper sulphate against haemiglobincyanide reference method. Clin Lab Haem. 2004;26:253-258.

37. Ingram CF, Lewis SM. Clinical use of WHO haemoglobin colour scale: validation and critique. J Clin Pathol. 2000;53:933-937.

38. Philipps RA, Van Slyke DD, Hamilton PB, Dole VP. Measurement of specific gravities of whole blood and plasma by standard copper sulphate solutions. J Biol Chem. 1950;183:305-330. 